\title{
Environmental Technologies in Housing Construction: Investment Features
}

\author{
Aleksandr V. Melnichuk ${ }^{1 *}$, Sergey A. Makushkin ${ }^{1}$, Kirill Lvovitch Manaenkov ${ }^{2}$, Mikhail \\ Nikolaevich Prokofiev ${ }^{3}$, Elvina Alekseevna Omshanova ${ }^{4}$
}

\author{
${ }^{1}$ Russian State Social University, Moscow, Russia \\ ${ }^{2} \mathrm{CEO}$ of Kvartirabezriskov LLC, Moscow, Russia \\ ${ }^{3}$ Federal State Educational Budgetary Institution of Higher Education "Financial University under the Government of the Russian Federation", Moscow, \\ Russia \\ ${ }^{4}$ Plekhanov Russian University of Economics, Moscow, Russia
}

Received: 14/02/2020

Accepted: 09/07/2020

Published: 20/09/2020

\begin{abstract}
In the present-day world, dominated by technological progress, humanity is beginning to realize the real danger of an environmental disaster, which can become a threat to the existence of contemporary civilization. This realization marked the beginning of the development of new types of economic activities that involve not only economic growth, but also positive impact on the environment and society. The use of environmental technologies in construction can serve an example of such activities and has significant development prospects because it simultaneously solves both social issues of increasing housing security and environmental issues, primarily the energy conservation issue. Based on an expert survey, the key drivers of supply and demand for investments in environmental technologies in the construction sector, as well as the benefits of implementing and using environmental investments, were identified. The article presents the investment experience of the EU countries in the housing development sector.
\end{abstract}

Keywords: Housing construction, Environmental technologies, Environmental investments, Environmental construction, Investment offer, Demand for investment, Driver

\section{Introduction}

Today's uncontrolled advanced use of factors of production, especially nonrenewable resources, as well as various emissions and pollutions from production activities lead to a significant and sometimes irreversible depletion of natural wealth and labor potential $[1,2]$. The ecosystem is on the verge of an ecological crisis, which affects, first of all, the social system, the human resource as a factor of economic growth, and the basis for accumulating civilizational values $[3,4]$. Understanding of such challenges to the harmonious development of the socioecological and economic system of society encourages economic science to develop new methodological approaches and practical mechanisms of social evolution to ensure sustainable development at different levels of economic policy decisionmaking. New approaches to socio-economic development and environmental management are emerging at the scientific and practical levels, which is reflected either in the emergence of new economic sectors or in a significant qualitative transformation of existing economic activities on an innovative and environmental basis [5, 6]. The active development of ecological construction over the past decades corresponds to this trend.

*Corresponding author: Aleksandr V. Melnichuk, Russian State Social University, Moscow, Russia. E-mail: melnichuk.a.v@bk.ru
According to A.N. Asaul, ecological (green) construction is a combination of the construction ecology components, namely urban ecology, biopositive construction, environmental reliability and safety, energy-efficient and energy-saving buildings and resources, as well as waste-free production, waste disposal, and eco monitoring [7].

At that, the development of ecotechnologies in housing construction acquires a special role, which could have a positive multiplier effect not only on the economy in general (that is inherent in housing construction as a type of economic activity), but also on the quality of housing conditions, housing provision, and the ecological condition at the local (regional) level. In this context, environmental technologies in construction, as a factor of sustainable development, should be perceived as the harmonious combination of resources, areas of investment, aspects of technological development, and institutional changes with the needs of present and future generations in a healthy human environment.

The researchers note that the lack of adequate environmentally safe housing conditions can lead to the degradation of the individual, an increase in the level of morbidity of the population, and as a result, to a decrease in labor productivity [8]. These technical-economic and environmental-medical problems complement the main social problem, which is the low level of housing provision for the population. Buildings constructed using environmental 
technologies can reduce energy consumption by 24-50\% [9], carbon dioxide emissions - by 33-39\% [10], water consumption - by $40 \%$ [11], and the amount of generated solid waste - by $70 \%$ [12]. That is, the main difference between such buildings is the application of the latest technologies that allow reducing energy consumption during the operation of houses, as well as their impact on the environment.

For a long time, there was an opinion that the construction of environmentally friendly houses costs much more than conventional new buildings. Actually, the amount of money spent on energy conservation is not so large. Usually, the construction of a house based on green technology costs just 10$20 \%$ more than the construction of an ordinary apartment building. However, the benefits for owners of such housing in the future are so obvious that such construction pays off already at the stage of selling apartments because a lot of residents of megacities in advanced countries prefer to pay a little more for their housing now to save significant amounts of money on heating, water and electricity bills in the future [13].

Thus, premises built using environmental (green) technologies, depending on their type, will recoup during the period up to 20 years. But, as experts clarify, the point here is not that the costs should be recouped as quickly as possible, but that the benefit from the use of energy-efficient technologies increases the more, the longer the building serves [14]. It is necessary to take into account that the payback period of intelligent objects, which take into account the requirements of environmental construction in terms of automation and dispatching, is just 3-7 years, while the payback period of typical buildings, according to experts, varies from 4 to 10 years [15]. Despite the significant contribution of scientists to the issues concerning post-industrial factors in the development of construction activities, the specifics of investing in environmental construction require more in-depth research.

Today, gradual complete reorientation of the Russian industrial and economic complex to modern high-tech and nature-saving approaches and technologies in the design, production, organization, and marketing of products and services is an acute problem. All this requires significant amounts of funding for various areas of production and commercial activities. Many scientists consider environmentally-oriented investments as part of a single investment process. Thus, T.B. Bardakhanova notes that environmentally oriented investment is an investment that is carried out within the entire national economic complex and takes into account environmental goals and priorities. At that, environmentally oriented investments are understood by the author as all types of values invested by the investor (property, financial, and intellectual values), aimed at reducing and eliminating the negative anthropogenic impact on the environment, as well as preserving, improving and using optimally the natural resource potential of territories, forming the country's environmental security, which contributes to achieving environmental, social, economic and political results [16].

Researchers believe that any investment, regardless of the investment object, can be characterized as having certain environmental impact and an environmental effect, since any production process has always the impact on the environment. This environmental effect is the essence of the environmental performance of investments in the field of material production. It causes changes in environmental parameters and affects both internal and external investment process entities [17].

Bulgakova L.M. and R.N. Plotnikova define ecologization of the economy as a purposeful process of economic transformation aimed at reducing the integral ecodestructive impact of the goods production and consumption processes and services per unit of the total social product. It is implemented through a system of organizational measures, innovative processes, restructuring of production and consumer demand, technological conversion, rationalization of nature management, and the transformation of environmental activities, which are implemented at both macro- and microeconomic levels [18].

Egorova M.S. restricts environmental investments to those invested in nature management, investment aimed at improving and/or restoring the environment, and reducing the level of environmental pollution at existing and newly created enterprises. Thus, the researcher defines environmental investments as a contribution to rational resource management, which are grouped by elements of rational nature management (use of natural resources, their restoration, and protection), nature management entities, and by the areas of ensuring the reproduction process (environmental, social, and economic) [19]. Nehrt K. considers environmental investments as those aimed at creating financial funds whose production and operation process, first, reduces the use of natural resources and, second, mitigates (or eliminates) the adverse impact on the environment and human health [20]. One of the innovative approaches to defining the essence of environmentally oriented investments is to emphasize them as an independent tool of the environmental management system of economic activities. At that, researchers reveal environmentally-oriented investment as one of the economic tools used by business entities in the implementation of investment activities to limit, reduce, or eliminate negative environmental impact, and obtain a positive effect. The beneficial effect on the environment is ensured by optimizing the resource cycle of production. Identifying the need for such investments requires continuous attention since the positive and negative effects of man-made impacts are external to the production process and are beyond the focus of producers' interests [21].

The purpose of the present article is to analyze the features of investment and identify the key drivers of supply and demand for investments in environmental technologies in the construction sector. The research hypothesis is formulated as follows: the key drivers of demand and supply for investments in environmental technologies in the housing construction sector differ significantly from those in the commercial segment. Based on the research results, it can be concluded that the goal set in the study was achieved.

\section{Methods}

During the research, the following research methods were applied: (a) analysis of scientific literature on the problem of investment in environmental technologies in the construction sector and (b) an expert survey to determine the goals of environmental technologies in the international practice of housing construction and methods for their implementation, the key drivers of supply and demand for investment in environmental technologies in the construction sector, as well as the benefits of implementing and using environmental investments. The expert online survey was attended by 45 experts, employees of construction companies operating in the 
housing construction market.

\section{Results}

Based on the expert survey, the key drivers of supply and demand for investments in environmental technologies in housing construction were determined. All drivers were ranked from one point (priority significance) to 21 points (the lowest significance) taking into account their importance for enhancing the inflow of investment in environmental technologies in the relevant construction sector (to compare, the commercial and residential sector were considered) (Tables 1-3). Regarding the demand for investments in environmental technologies in housing construction, the main factor here is the individual solvency and its priorities and preferences, the ease of investment in terms of financial and nonfinancial transaction costs, the need for flexible, custom-made, specialized financial products, and the need for financial support for such investments (Table 1).

Therefore, it is necessary to change the behavior of homeowners in terms of their expenditures through the implementation of simple, attractive, specially designed retail offers with a low-interest rate for financing energy-efficient environmental projects for various income groups of the population. In contrast to commercial construction, residential construction is distinguished by more important demand for specially designed products capable of renovation. And only in this sector, the cost of energy resources was very significant as a stimulus for the demand for investment in construction. As for the drivers of investment supply in commercial and housing construction, according to experts, they are very similar in many ways and, consequently, there is a very high level of consistency between the commercial and private housing sectors (Table 2). Thus, standardization, the stability of the regulatory framework, transaction costs, risk assessment, the overall risk-return ratio, the price of energy resources, the development of financing mechanisms, and the accessibility of information about expected effects are crucial factors for stimulating supply in both segments. The relational base and standardization are the priority drivers but there is the high significance of reduced transaction costs and a developed financing mechanism. Based on the previous analysis, a summary Table reflecting prioritization of the key drivers of supply and demand for investment in environmental technologies in the construction sector was composed taking into account the first 10 factors (Table 3). As can be seen from Table 3, for the housing construction sector, the key drivers differ significantly from those for the commercial construction segment. This once again confirms the need for an individual approach when planning and implementing economic policies for investment in environmental technologies in construction. Nevertheless, a strong and effective regulatory system is a priority driver of demand, which unites all segments of the construction market.

\section{Discussion}

Summing up the previous results, experts determine the types of benefits that will appear when investing in environmental technologies in housing construction, at both the micro- and macro levels (Table 4).
Table 1: Prioritization of key drivers of demand for investment in environmental technologies in the construction sector

\begin{tabular}{|c|c|c|c|}
\hline \multirow[t]{2}{*}{ No. } & \multirow[t]{2}{*}{ Key driver } & \multicolumn{2}{|c|}{$\begin{array}{c}\text { Subsector of } \\
\text { construction (rank) }\end{array}$} \\
\hline & & Commercial & Housing \\
\hline 1 & Standardization & 2 & 11 \\
\hline 2 & $\begin{array}{l}\text { Clear business plan for energy } \\
\text { efficiency }\end{array}$ & 4 & 9 \\
\hline 3 & $\begin{array}{l}\text { The effective forced regulatory } \\
\text { system }\end{array}$ & 6 & 8 \\
\hline 4 & $\begin{array}{l}\text { Awareness of decision-making } \\
\text { leaders }\end{array}$ & 10 & 12 \\
\hline 6 & $\begin{array}{l}\text { Accessibility of specially designed } \\
\text { financial products }\end{array}$ & 3 & 5 \\
\hline 7 & Transaction costs and simplicity & 5 & 2 \\
\hline 8 & $\begin{array}{l}\text { Quality of legislation regarding the } \\
\text { terms and scope of renovations }\end{array}$ & 11 & 13 \\
\hline 9 & $\begin{array}{l}\text { Stability of regulatory } \\
\text { policy/legislation }\end{array}$ & 9 & 16 \\
\hline 10 & Technical support and consulting & 12 & 10 \\
\hline 11 & Tax support & 1 & 4 \\
\hline 12 & $\begin{array}{l}\text { Argument base (social benefits } \\
\text { and costs) }\end{array}$ & 14 & 14 \\
\hline 13 & Individual solvency (of the owner) & 8 & 1 \\
\hline 14 & $\begin{array}{l}\text { Awareness, communication, and } \\
\text { marketing }\end{array}$ & 7 & 6 \\
\hline 15 & $\begin{array}{l}\text { Measurement, reporting, } \\
\text { verification, quality control }\end{array}$ & 18 & 19 \\
\hline 16 & Price of energy resources & 20 & 7 \\
\hline 17 & Mandatory energy efficiency audit & 16 & 18 \\
\hline 18 & $\begin{array}{l}\text { Accessibility of information about } \\
\text { similar projects }\end{array}$ & 17 & 17 \\
\hline 19 & $\begin{array}{l}\text { Definition and general } \\
\text { understanding of the savings } \\
\text { on energy costs }\end{array}$ & 19 & 15 \\
\hline 20 & Personal priorities & 13 & 3 \\
\hline 21 & $\begin{array}{l}\text { Communication between market } \\
\text { agents }\end{array}$ & 15 & 20 \\
\hline
\end{tabular}

Note: composed based on an expert survey

According to experts, green building, especially its residential sector can have a beneficial effect (and is already showing such an effect in advanced economies) on all components of sustainable development. However, environmental housing construction in Russia is still at the stage of waiting for growth and immature development (represented by single objects in different regions of the country). The immaturity of the ecoconstruction market is also evident in the lack of common opinion concerning the kind of real estate, whose construction is most profitable using environmental technologies. Experts consider residential real estate to be the most promising in this sense, especially the construction of private houses and cottages since the end-consumers of such objects are more aware of contemporary energy-efficient technologies. The proposals of experts on the implementation of environmental technologies in the construction sector, in general, are shown in Table 5. 
Table 2: Prioritization of key drivers of supply of investments in environmental technologies in the construction sector

\begin{tabular}{|c|c|c|c|}
\hline \multirow[t]{2}{*}{ No. } & \multirow[t]{2}{*}{ Key driver } & \multicolumn{2}{|c|}{$\begin{array}{l}\text { Subsector of construction } \\
\text { (rank) }\end{array}$} \\
\hline & & Commercial & Housing \\
\hline 1 & Standardization & 2 & 1 \\
\hline 2 & Stability of legislation & 3 & 4 \\
\hline 3 & $\begin{array}{l}\text { Increased confidence of investor } \\
\text { and changes in risk perception }\end{array}$ & 4 & 5 \\
\hline 4 & Transaction costs and simplicity & 1 & 2 \\
\hline 5 & $\begin{array}{l}\text { Measurement, reporting, } \\
\text { verification, and quality control }\end{array}$ & 8 & 10 \\
\hline 6 & $\begin{array}{l}\text { Owner's approach to risk } \\
\text { assessment }\end{array}$ & 5 & 6 \\
\hline 7 & Risk-return targeted indicators & 7 & 7 \\
\hline 8 & $\begin{array}{l}\text { A clear business plan for } \\
\text { implementing environmental } \\
\text { technologies for energy } \\
\text { efficiency }\end{array}$ & 9 & 11 \\
\hline 9 & $\begin{array}{l}\text { Reliability of information about } \\
\text { similar projects }\end{array}$ & 10 & 12 \\
\hline 10 & Price of energy resources & 14 & 8 \\
\hline 11 & $\begin{array}{l}\text { Individual solvency (of the } \\
\text { owner) }\end{array}$ & 11 & 9 \\
\hline 12 & $\begin{array}{l}\text { Definition and general } \\
\text { understanding of the savings } \\
\text { on energy costs }\end{array}$ & 17 & 16 \\
\hline 13 & Financial management & 15 & 15 \\
\hline 14 & Funding mechanism & 6 & 3 \\
\hline 15 & $\begin{array}{l}\text { Supply of financial resources } \\
\text { within the framework of } \\
\text { environmental investments }\end{array}$ & 12 & 14 \\
\hline 16 & $\begin{array}{l}\text { Argument base (social benefits } \\
\text { and costs) }\end{array}$ & 20 & 13 \\
\hline 17 & The capital market condition & 16 & 19 \\
\hline 18 & Tax support & 13 & 17 \\
\hline 19 & $\begin{array}{l}\text { Communication between market } \\
\text { agents }\end{array}$ & 18 & 20 \\
\hline 20 & $\begin{array}{l}\text { Awareness, communication, and } \\
\text { marketing }\end{array}$ & 19 & 18 \\
\hline 21 & Technical support and consulting & 21 & 21 \\
\hline
\end{tabular}

Note: composed based on an expert survey

In the context of the above, it is necessary to consider the experience of EU countries on investing in environmental technologies in the construction sector. Green building in the EU represents a developed market, and in the coming years, a progressive trend is predicted to attract new companies to this industry sector. On average, in Europe, a third of construction projects is carried out following the principles of permanence, and all international expert agencies recognize the EU's leadership in implementing environmental technologies in the construction of all types of structures, including residential ones. This is facilitated by more than a decade of the practice of panEuropean initiatives supporting environmental construction, and the continuous improvement of the relevant regulatory framework in the EU, as well as its enhanced implementation in the participating countries. European research on reducing greenhouse gas emissions shows that it is in the construction sector that there is a large undiscovered long-term, the costeffective potential for improving the environment and saving energy. Estimations show that from EUR 60 bln to EUR 100 bln should be invested annually in housing construction and renovation in the EU to achieve the goals of environmental friendliness and energy efficiency. So far, the corresponding investments amount to less than half of these needs and are five times lower than the necessary level [22].

Table 3: Prioritization of key drivers of supply and demand for investment in environmental technologies in the construction sector (top 10 factors)

Commercial construction Housing construction
(owner-occupied housing)

1. Tax support 1. Individual solvency (of the 2. Standardization owner)

3. Accessibility of specially 2 . Transaction costs and designed financial products simplicity 4. A clear business plan for 3. Personal priorities implementing environmental 4. Tax support technologies for energy 5. Accessibility of specially efficiency

5. Transaction costs and $\checkmark$ simplicity

E. 6 . The effective forced ¿ regulatory system

7. Awareness, communication, and marketing

8. Individual solvency (of the owner)

9. Stability of regulatory policy/legislation 10. Awareness of decisionmaking leaders

1. Standardization

2. Transaction costs and simplicity designed financial products 6. Awareness, communication, and marketing

7. Price of energy resources 8. The effective forced regulatory system 9. A clear business plan for implementing environmental technologies for energy efficiency 10. Technical support and consulting

3. Personal priorities $\quad 3$. Stability of legislation

4. Tax support 4. Increased investor confidence

5. Accessibility of specially and risk perception

designed financial products 5 . Homeowner's approach to

6. Awareness,

communication, and

risk assessment

6. Funding mechanism

marketing

i 7 . Price of energy resources

regulatory system

9. A clear business plan for 9. Stability of regulatory implementing environmental policy/legislation

technologies for energy

efficiency

10. Technical support and

10. Definition and a general understanding of the savings on energy costs consulting

\section{Note: composed based on an expert survey}

Besides, while the European industry is a world leader in environmental friendliness and energy efficiency, the increased scope of investments in this area will enhance its global 
competitiveness, protect against energy price volatility, and ensure further reduction of costs in all economic sectors.

Table 4: Effects of implementing and using investments in environmental technologies in housing construction

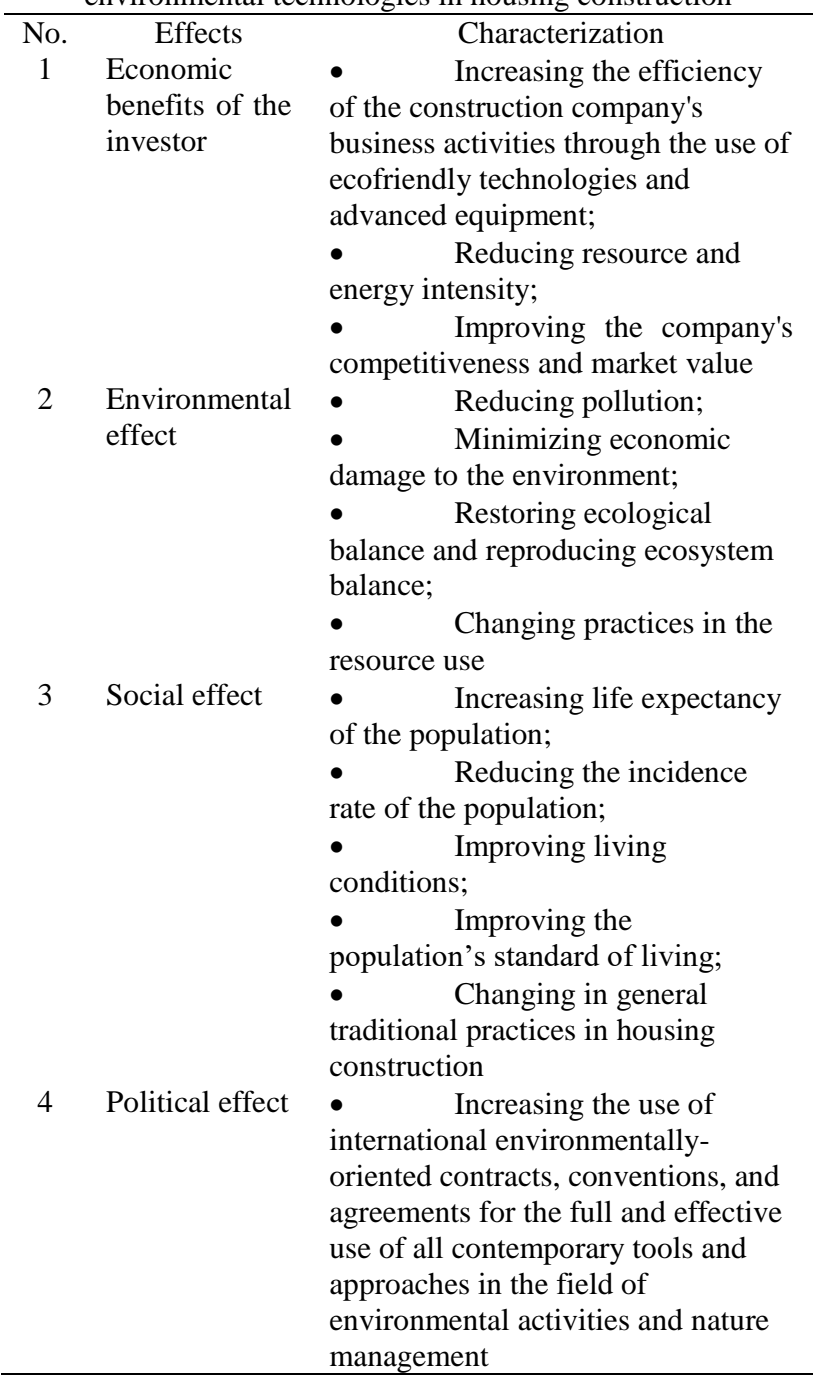

Note: composed based on an expert survey

Researchers note that residential buildings account for the largest share of European final energy consumption (40\%) and represent the greatest potential for achieving energy-saving goals because $75 \%$ of existing buildings in the EU were built during periods of lack of energy-efficient technologies [23]. Residential buildings are long-term assets and, as practice shows, remain in operation for at least 50 years. Accordingly, $75-90 \%$ of buildings will remain in operation until 2050. With a low level of the demolition of buildings $(0.1 \%$ per year), a low level of renovation (1.2\% per year), and the transition to almost zero energy consumption of newly constructed buildings ( $1 \%$ per year), the effectiveness of solving the energy problem in the European construction complex is in great doubt and is mainly related to reconstruction and environmental investment in the existing housing stock in the form of renovation projects and retrofitting [24]. However, according to European researchers, the growth of investment in environmental technologies in construction cannot be achieved only by market forces. They must be complemented by public funds, a pragmatic, predictable, long-term and supportive regulatory environment, and a fundamental change in the behavior of actors in different types of construction. These factors will be necessary to ensure that the use of environmental technologies in construction will increase at least three times by 2025 compared to 2015 [25].

Table 5: Recommendations for improving policies to encourage investment in green construction

To policy developers To market actors

Existing legislation in the field Providing key decisionof construction must be fully makers (owners and implementable, coordinated, and managers) with a clear consistently applied

business case that will increase their awareness of the benefits of environmental technologies and support them with evidence

Future directions in the regulation of the construction Simplifying the process of getting correct sector should ensure coordinated environmental data for and consistent forced and decision-makers permissive measures to improve the environmental friendliness of buildings

High-quality solutions and low transaction costs can be implemented using easily accessible data and standard procedures

Reporting, accounting and procurement procedures should facilitate rather than hinder appropriate investments in green process construction

Full-scale improvements in the environmental friendliness of residential buildings can occur only under conditions of coordinated stimulation of drivers of investment demand and supply in this segment

Improving processes and standards for marking and certifying environmental technologies in construction

Developing standards for each element of the green building investment

Ensuring the leverage effect in the financing of environmental technologies in the housing sector through optimal use of investment funds

Note: composed based on an expert survey

In this regard, at the end of 2013, a special expert working group was established jointly by the EU and the UN called the Energy Efficiency Financial Institutions Group (EEFIG) [1]. The task of this organization is to find ways to overcome wellknown challenges in the EU on the way to long-term and largescale financing of environmental and energy-efficient projects and to strengthen the attraction of investment in sustainable development. Today, more than 120 active members have joined this organization. They represent public and private financial structures, various industries, investment groups, research and 
innovation companies, small and medium-sized enterprises, public expert organizations, the International Energy Agency (IEA), the European Commission, and the UN Environment Program Finance Initiative (UNEP FI).

To make EEFIG's approach and recommendations towards increasing investment in environmental technologies in construction more practical, the construction sector was segmented into three parts: commercial buildings, state-owned buildings, and private residential buildings. The first type includes shopping centers, offices, restaurants, hotels, hospitals, warehouse and garage buildings, stores, etc. The second type includes buildings directly occupied by the central, regional, or local government or its authorized bodies. This segment also includes government-owned buildings, such as social housing, schools, and universities. In the EU, they make up about $12 \%$ of the total stock of buildings. The third type includes residential buildings, multifamily, combined buildings, and single-family houses. Both private and public buildings are additionally divided into rental housing and owner-occupied housing. The EEFIG advocates the priority of increasing the demand for environmental investments in each segment of the construction sector. In turn, it will boost the supply of finance for environmental construction projects.

\section{Conclusions}

The research results have confirmed the hypothesis that the key demand and supply drivers for investments in environmental technologies for the housing construction sector differ significantly from those in the commercial segment.

This once again confirms the need for an individual approach when planning and pursuing an economic policy. However, a strong and effective forced regulatory system is a priority driver of demand, which unites all segments of the construction market. Regarding the demand for environmental investments in housing construction, the main factor here is the individual solvency and its priorities and preferences, the ease of investment in terms of financial and nonfinancial transaction costs, the need for flexible, custom-made, specialized financial products, and the need for financial support for such investments. Therefore, it is necessary to change the behavior of homeowners through the implementation of simple, attractive, specially designed retail offers with a low-interest rate for financing environmental projects for groups of the population, different in their income.

The study of the economic reasoning for the application of environmental technologies in housing construction may become the prospect of further research.

\section{Aknowledgment}

Journal editorial doard thanks following reviewers to review this article.

\section{Ethical issue}

Authors are aware of, and comply with, best practice in publication ethics specifically with regard to authorship (avoidance of guest authorship), dual submission, manipulation of figures, competing interests and compliance with policies on research ethics. Authors adhere to publication requirements that submitted work is original and has not been published elsewhere in any language.

\section{Competing interests}

The authors declare that there is no conflict of interest that would prejudice the impartiality of this scientific work.

\section{Authors' contribution}

All authors of this study have a complete contribution for data collection, data analyses and manuscript writing

\section{References}

1 Zhukov RA., Kuznetsov GV, Fomicheva IV, Myasnikova EB, Vasina MV, Tsigler MV. A Model of Socio-Ecological and Economic System: The Tula Region of the Russian Federation. J. Environ. Manag. Tourism. 2020;10(7):1539-1558.

2 Kubenkulov K, Naushabaev A, Abdirahymov N, Rustemov B, Bazarbaev S. Particularities of Forming Desert Pastures Near Settlements of Southern Balkhash (Kazakhstan). J. Eco. Engin. 2019;20(8):129-134.

3 Novoselov A, Novoselova I, Aliev, R. Avramenko A. Preventing Regional Social and Environmental Conflicts During Oil Pipeline Construction Projects. Entrepreneurship Sustainability Issues. 2019;7(1).

4 Bakinova TI, Darbakova NE, Kazakova GYa, Sangadzhieva SA, Darbakova IE. Information Support of Monitoring as a Tool of Ecological Optimization of Agricultural Land Use. J. Environment. Manag. Tourism. 2019;10(1):195-201.

5 Myasnikova OYu, Lysytska SM, Shcherbakova NS, Shamsheev SV, Spitsyna TA, Kubasova EI. Ecological Approach in Managing the Technology of Oil Refineries. Int. J. Energy Econ. Policy. 2019;9(3).

6 Malakhova TN. Sovremennoe sostoyanie i tendencii razvitiya ekologicheskih innovacij $\mathrm{v}$ ekonomike Rossii [Current status and trends in the development of environmental innovations in the Russian economy]. Econ. Sci. 2015;1:42-49.

7 Asaul AN, Ivanov SN. Osnovnye napravleniya razvitiya «zelenogo» stroitel'stva [Main development trends of green construction]. Bull. Pacific State Univ. 2015;1(36):169-178.

8 Guseva TV, Pankina GV, Petrosyan ER. Zelenye standarty: sovremennye metody ekologicheskogo menedzhmenta v stroitel'stve [Green standards: Contemporary methods of environmental management in construction]. Competence. 2012;8:22-28.

9 Lacasse MA. Materials and technology for sustainable construction. Build. Res. Inf. 1999;27(6):405-408

10 Galante A., Pasetti, G. A methodology for evaluating the potential energy savings of retrofitting residential building stocks. Sustainable Cities and Society. 2012;4:12-21.

11 Darko A, Chan, APC, Ameyaw, EE, He BJ, Olanipekun AO. Examining issues influencing green building technologies adoption: The United States green building experts' perspectives. Energy Build. 2017;144:320-332.

12 Perez-Lombard L, Ortiz J, Pout C. A review of the buildings' energy consumption information. Energy and Buildings. 2008;40:394-398.

13 Shazmin SAA, Sipan I, Sapri M. Property tax assessment incentives for green building: A review. Renewable Sustainable Energy Rev. 2016;60:536-548

14 Neyestani B, Juanzon JBP. Identification of a set of appropriate Critical Success Factors (CSFs) for successful TQM implementation in construction, and other industries. Int. J. Adv. Res. 2016;4(11):1581-1591.

15 Silverman N, Mydin A. Green technologies for sustainable building. Acta Technica Corviniensis - Bull Engin. Tome. 2014;7(3):87-94.

16 Bardakhanova TB. Metodologiya organizacii privlecheniya investicij $\mathrm{v}$ ekologicheski orientirovannye proekty $\mathrm{i}$ programmy [Organizational methodology to attract investments in environmentally oriented projects and programs]. Ph.D. thesis. Moscow; 2013. 
17 De Sousa GVM., Rodeiro-Pazos D. Do short and long-term environmental investments follow the same path? Corporate Soc. Responsibility Environment. Manag. 2017;25(1):14-28.

18 Bulgakova LM, Plotnikova RN. Problemy ekologizacii ekonomiki i ekonomizacii ekologii [Problems of ecologization of economy and economization of ecology]. Fundamental Studies. 2009;5:121-122.

19 Egorova MS. Ekologicheskie investicii kak put' vosstanovleniya ekonomiki [Environmental investments as a way to restore the economy]. Bull. Siberian Sci. 2011;1(1):474-480.

20 Nehrt C. Timing and intensity effects of environmental investments. J. Econ. Manag. Strat. 1996;17(7):535-547.

21 Vörösmarty C, Rodríguez O. V, Koehler D, Klop P, Spengler J, Buonocore J, Cak A, Tessler Z, Corsi F, Green P, Sánchez R. Scientifically assess the impacts of sustainable investments. Sci. 2018;359(6375):523-525.

22 Multiannual Financial Framework Beyond 2020: five principles to improve how the EU finances building renovation and a nearly zero energy building stock. [Internet]. Buildings Performance Institute Europe (BPIE); 2018. [cited 2020 Jan 13]. Available from: http://bpie.eu/wp-content/uploads/2018/03/FINAL-MFF-visionpaper.pdf

23 Weber R, Lidmo RM, Neighbourhood results: Towards efficient and impactful green building projects in Europe. [Internet]. J. EU Policy, [cited 2020 Jan 13]. Available from: https://www. interregeurope.eu/fileadmin/user_upload/tx_tevprojects/library/file_ 1543836346.pdf

24 Smart finance for smart buildings: Investing in energy efficiency in buildings. [Internet]. European Commission; 2018. [cited 2020 Jan 13]. Available from: https://ec.europa.eu/info/news/smart-financesmart-buildings-investing-energy-efficiency-buildings-2018-feb07_en

25 Innovating for a sustainable built environment. CRH Sustainability Report. [Internet]. CRH; 2018. [cited 2020 Jan 13]. Available from: https://www.crh.com/media/1022/crh-sustainability-report-2018.pdf 